\title{
PINNA MURICATA.
}

\section{$* * * * 4 * * * 4 * * * * * * * * * * * * * 4$ \\ CHARACTER GENERICUS.}

Animal Limax.

Testa subbivalvis fragilis, erecta hians, emittens barbam byssinam.

Cardo edentulus, coalitis in unam valvis.

Lin. Syst. Nat. Gmel. p. 3363.

CHARACTER SPECIFICUS, Ec.

PINNA testa striata, squamis concavis, ovatis, acutis.

Lin. Syst. Nat. p. 1160.

Concha Pinna.

Hasselq. itin. 447.

Varietates potius quam distincta species sunt plures hujus generis.

Genus Pinna, cujus nonnullæ species in peramplam crescunt magnitudinem, præter cæteros characteras hoc quoque habet insigne, quod animal testam incolens ab apice linguæ tubulatæ sæpissime exertæ et retractæ guttulam glutinosam deponat, unde efficitur quasi sericus innumerarum fibrarum fasciculus, e quo suspensum rupibus aliisque id genus 
tuto se possit affigere. Inter species minores est Pinna muricata, longa nempe sex vel octo uncias. Color et superficiei scabrities longe variant. Plerumque tamen color exterior est fusco-saturatior, interior subrubrus cum nitore quodam margaritaceo. Pinnarum byssus seu sericum aureo-fuscum in chirothecas aliasque parvulas vestes interdum convertitur ab incolis orarum mediterranei maris, Italiæ nempe, Siciliæ, \&c. \&c. Notandum porro est posse se suspendere sericis filamentis, ab animali testam incolente contextis, Pinnæ generi non proprium omnino et peculiare esse, sed et a nonnullis Mytylorum speciebus, parcius tamen et contractius, eandem artem exerceri. 


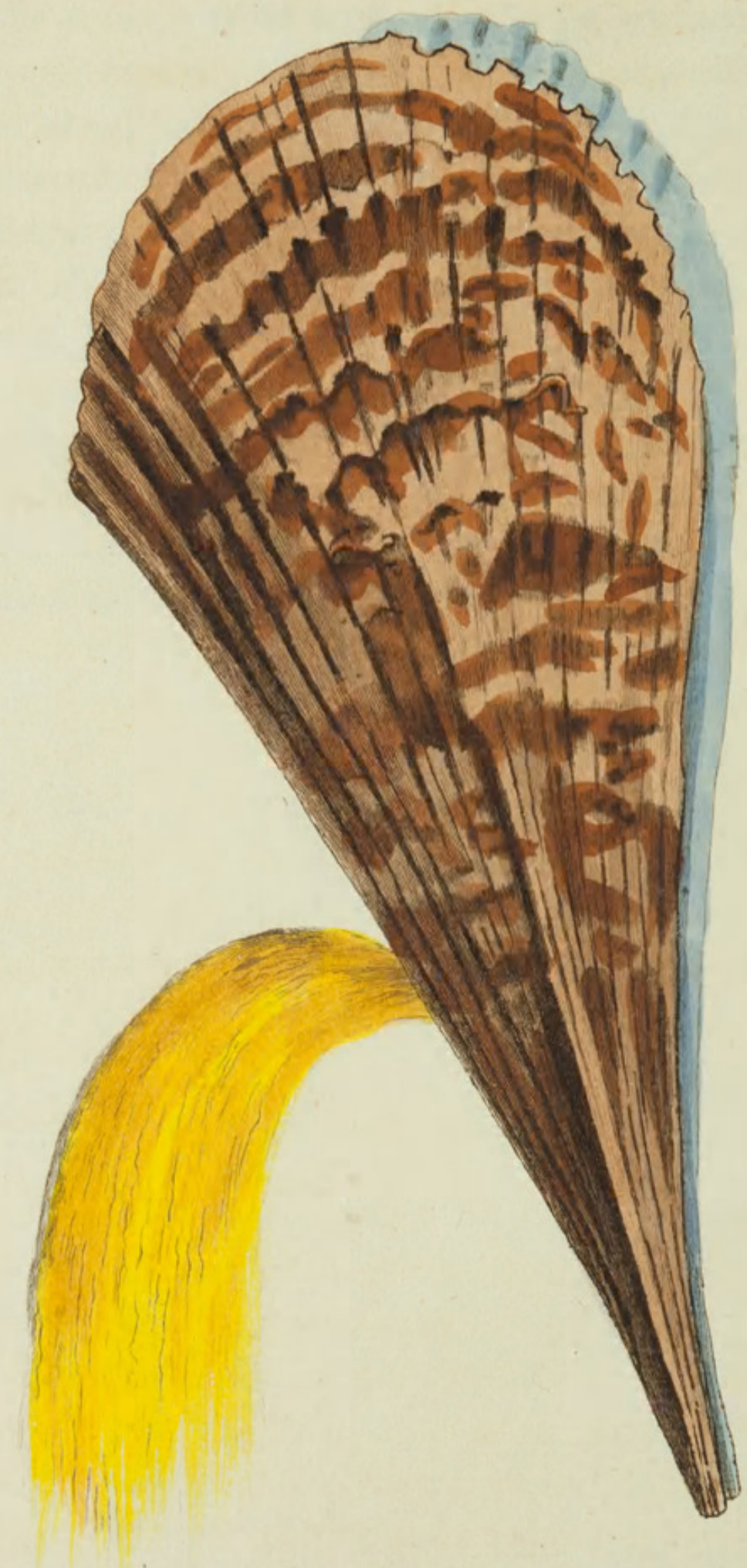

ar 


\section{THE MURICATED PINNA.

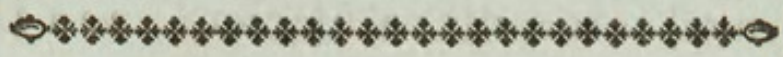

\section{GENERIC CHARACTER.}

Animal allied to a Limax.

Shell subbivalve, fragile, gaping at the upper part, emitting a beard or tuft of silken filaments.

Hinge toothless, the valves coalescing together.

\section{SPECIFIC GHARACTER, Ëc.}

PINNA with striated shell, with acute, ovate, concave scales.

Gualt. test. t. 79. f. D.

Seb. 3. t. 22.

Obs. Several of the Pinnce are considered by Linnæus as varieties rather than distinct species.

The genus Pinna, of which some species grow to a very large size, is distinguished, among other circumstances, by the remarkable power which the inhabiting animal possesses, of affixing itself at pleasure to rocks, or other substances, by a vast number of fine silky threads or filaments, which it forms by extending 
extending its tubular trunk or tongue, and discharging from its tip a minute drop of gluten, which, by the retraction of the same organ, is of course formed into a silken filament; and this operation being several thousand times repeated, a thick and beautiful tuft of silky fibres is composed, by the help of which the animal is securely fastened or anchored in such places as it finds convenient. The Pinna muricata is among the smaller species of this genus; measuring about six or eight inches in length. In color, as well as in the degree of roughness of its external surface, it varies considerably. It is commonly of a deep brown externally, and of a reddish tinge, varied with a degree of pearly lustre internally. The silk or byssus of the Pinnæ is of a rich golden brown color, and is occasionally manufactured into gloves, \&c. by the inhabitants of those parts of the Mediterranean coasts where it most abounds, viz. on some of the coasts of Italy and Sicily. It should be added, that the power of adhering by means of silken filaments thus drawn from the inhabiting animal, is not entirely confined to the genus Pinna, but takes place, in a smaller degree, in some species of Mytilus. 


\section{$2 \mathrm{BHL}$ Biodiversity Heritage Library}

Shaw, George. 1800. "The Muricated Pinna, Pinna muricata [PI. 483]." The Naturalist's Miscellany 12(CXXXV), https://doi.org/10.5962/p.310929.

View This Item Online: https://www.biodiversitylibrary.org/item/278722

DOI: https://doi.org/10.5962/p.310929

Permalink: https://www.biodiversitylibrary.org/partpdf/310929

\section{Holding Institution}

Museums Victoria

\section{Sponsored by}

Atlas of Living Australia

\section{Copyright \& Reuse}

Copyright Status: Public domain. The BHL considers that this work is no longer under copyright protection.

This document was created from content at the Biodiversity Heritage Library, the world's largest open access digital library for biodiversity literature and archives. Visit BHL at https://www.biodiversitylibrary.org. 